\title{
EFEKTIVITAS PERATURAN DAERAH NOMOR 2 TAHUN 2000 TENTANG PEMBERANTASAN PELACURAN DI DESA SANUR KAUH DENPASAR SELATAN
}

\section{MADE RAHMAWAN ADITYA WISMARA ${ }^{1)}$, ANAK AGUNG PUTU WIWIK SUGIANTARI ${ }^{2)}$, LIS JULIANTI'}

\author{
${ }^{1)}$ Mahasiswa Tingkat Akhir, ${ }^{2,3)}$ Dosen Program Studi Ilmu Hukum UNMAS Denpasar \\ e-mail: ${ }^{1)}$ adityawismara@gmail.com, ${ }^{2)}$ wiwiksugiantari@yahoo.com, ${ }^{3)}$ julianti.lis@gmail.com
}

\begin{abstract}
ABSTRAK
Tujuan penelitian ini adalah untuk mengetahui efektivitas peraturan daerah nomor 2 tahun 2000 tentang pelacuran di desa sanur kauh dan mengetahui hambatan-hambatan yang dihadapi dalam hal memberantas pekerja seks komersial di desa sanur kauh. Dalam penelitian ini analisi data tidak keluar dari lingkup sampel. Bersifat deduktif, berdasarkan teori atau konsep yang bersifat umum. Pendekatan deskriptif ditujukan untuk mendeskripsikan fenomena-fenomena yang ada, baik fenomena alamiah maupun fenomena buatan manusia. Fakta sosial akan diperoleh dari pemerincian terhadap kegiatan, perilaku, tindakan orangorang serta juga keseluruhan kemungkinan interaksi interpersonal, kemudian disajikan kepada orang lain dengan lebih jelas tentang apa yang di dapatkan dari lapangan. Kepada Pemerintah Desa melakukan tindakan persuasif, melakukan pendekatan terhadap tokoh-tokoh masyarakat di Desa Sanur Kauh, agar mereka membantu pemerintah desa untuk melakukan sosialisasi mengenai dampak negatif dari praktik pelacuran. Kemudian kepada Pemerintah Kota dan Pemerintah Desa bersinergi untuk melakukan pemberantasan terhadap praktik pelacuran.
\end{abstract}

Kata Kunci :Efektivitas, Perda, pelacuran

\section{ABSTRACT}

The purpose of this study is to determine the effectiveness of regional regulation number 2 of year 2000 regarding prostitution in the village of Sanur Kauh and to find out the obstacles faced in terms of eradicating commercial sex workers in the village of Sanur Kauh. In this study data analysis is not offside the scope of the sample. This research is deductive, based on theories or general concepts. Descriptive approach is intended to describe the phenomena that exist, both natural phenomena and man-made phenomena. Social facts will be obtained from a breakdown of the activities, behavior, actions of people as well as the overall possibility of interpersonal interaction, then presented to others more clearly about what is obtained from the field. The Village Government took persuasive action, approached community leaders in the Sanur Kauh Village, so that they can help the village government to disseminate the negative impacts of prostitution. Then the City Government and Village Government work together to eradicate the practice of prostitution.

Keywords: Effectiveness, Perda, prostitution

\section{PENDAHULUAN}

\section{Latar Belakang}

Pulau Bali merupakan salah satu Provinsi di Indonesia dan salah satu Provinsi yang memiliki sektor industri pariwisata yang berkembang sangat pesat. Pulau Bali memang tidak pernah kehabisan bahan untuk tebar pesona, bukan dari sisi keindahan alamnya saja, tapi kekayaan seni dan budaya yang syarat akan nilai sejarah juga memiliki daya tarik yang besar. Provinsi Bali memiliki ibu kota yaitu Kota Denpasar. 
Kota Denpasar merupakan salah satu daerah pariwisata yang banyak dikunjungi wisatawan, untuk tempat wisata budaya dan sejarah, kota Denpasar memiliki Monumen \& Museum Bajra Sandi, museum Bali, monumen puputan Badung danTaman Werdhi Budaya Art Centre Bali, selain tempat wisata budaya dan sejarah, objek wisata lainnya yang banyak dikunjungi wisatawan yaitu Hutan Bakau yang terletak di Desa Suwung, Denpasar Selatan. Kemudian di bagian timur Kota Denpasar tepatnya di Desa Sanur merupakan daerah yang paling banyak dikunjungi wisatawan asing, hal itu membuat desa sanur sebagai salah satu kawasan pariwisata favorit di kota denpasar .

Setiap daerah pariwisata pasti akan memberikan dampak bagi setiap kalangan yang berkecimpung di dalam pariwisata. Seperti yang kita ketahui bersama, kegiatan pariwisata dapat memberikan dampak positif dan negatif bagi yang berkecimpung di dalam kegiatan pariwisata ini baik dari objek wisatanya, masyarakat sekitar maupun pemerintah daerahnya. Dampak positif dari pariwisata : Terciptanya lapangan kerja di bidang pariwisata, Meningkatakan pendapat daerah khususnya daerah-daerah wisatawan, Penguatan dan pertukaran budaya dan Kesadaran masyarakat terhadap konservasi. Dampak negatif dari pariwisata :Kepadatan dan Kenyamanan, Mundurnya aktivitas gotong royong, Adanya komersialisasi kebudayaan dan Terjadinya gejala social deviance yang meliputi kejahatan, narkotika, maupun penyakit kelamin (Yulianto Bambang Setyadi (2007:22).

Desa Sanur digunakan sebagai tempat berwisata bagi wisatawan lokal maupun manca negara. Desa Sanur memiliki banyak pantai yang menyuguhkan pemandangan yang menakjubkan untuk para wisatawan yang berwisata, Desa Sanur memiliki berbagai pantai, yang masing-masing pantai memilki penggemarnya tersendiri, yaitu Pantai Matahari Terbit, Pantai Bali Beach, Pantai Segara, Pantai Sindhu, Pantai Semawang, serta Pantai Mertasari. Semua pantainya tersebut memilki keunikannya masing-masing. Desa Sanur, jika dilihat dari sudut pandang pantainya, merupakan pantai yang sangat menawan, wisatawan dapat melihat langsung keindahan panorama matahari terbit (sunrise).

Sebagai daerah wisata yang sangat terkenal, Desa Sanur juga terkena dampak negatif dari keberadaan pariwisata tersebut, salah satunya kegiatan prostitusi atau pelacuran, antara lain adanya gejala social deviance yaitu penyakit kelamin sering dijumpai di wilayah-wilayah pariwisata.

Menurut Kartono Kartini (2005 : 208), bahwa Pekerja Seks Komersial adalah perilaku menyimpang, dimana tindakan-tindakan tersebut tidak disetujui atau dianggap tercela dan akan mendapatkan sanksi negatif dari masyarakat, selain itu pekerjaan tersebut membawa dampak yang buruk terhadap kehidupan keluarga. Struktur sosial dalam kenyataannya telah membuat orang-orang tertentu di masyarakat untuk bertindak menyimpang dari pada mematuhi norma-norma sosial. Kegiatan ini sudah dikenal sejak dahulu diperkirakan sejak lama telah berlangsung pembelian budak seks dan hubungan seksual yang dilandasi hubungan yang semu.

Bisnis pelacuran ini merupakan kegiatan yang ilegal, karena secara moral kegiatan pelacuran bertentangan dengan nilai agama dan kesusilaan, selain itutumbuh suburnya kegiatan pelacuran merupakan bukti bahwa kegiatan ini masih menjadi momok untuk moral masyarakat. Semakin maraknya kasus prostitusi juga disebabkan tidak adanya efek jera yang dapat mengkriminalisasi pelaku prostitusi dalam hal ini PSK tersebut. Hal ini sesuai dengan apa yang dinyatakan oleh Anak Agung Gede Triyatna dan I Gusti Ngurah Parwata $(2019$; 14), bahwa pengaturan mengenai perbuatan PSK dalam hukum pidana Indonesia hingga saat ini belum diatur. Oleh karena itu, pelaku prostitusi dalam hal ini para PSK seringkali dianggap sebagai korban bukan pelaku tindak pidana.

Secara umum prostitusi itu sangat dekat dengan tindakan persetubuhan diluar nikah, yang mana dalam pandangan islam tindakan tersebut dapat dikatakan sebagai Zinah (Ahmad Wardi Muslich ; 2005 :3). Seperti yang diketahui penyakit masyarakat pelacuran atau pekerja seks komersial merupakan bisnis atau kegiatan yang menyimpang bahkan saat ini praktek tersebut secara terang-terangan beroperasi diantara masyarakat atau dilokasi-lokasi tertentu, bahkan pekerja seks komersial tidak takut dalam menjalankan kegiatan walaupun sudah ada aturan hukum yang mengancam tindakan praktek pelacuran tersebut. Pelacurpun dinilai mengotori nilai perkawinan yang sejati, yaitu dengan melakukan hubungan seks di luar status perkawinan yang sah. Jelas bahwa pekerjaan menjadi pelacur ini adalah sesuatu yang melanggar norma, namun yang dipikirkan dalam nalurinya adalah bagaimana mereka memenuhi kebutuhan hidupnya.

Faktor ekonomi merupakan faktor utama adanya kegiatan pelacuran, yang menyebabkan orang-orang berani melakukan apapun untuk memenuhi kebutuhan hidupnya, beberapa diantaranya ingin menghasilkan uang banyak melalui jalan pintas tanpa mempertimbangkan dampaknya. Selain berdampak negatif dengan nilai-nilai agama dan kesusilaan, pekerja seks komersial / pelacuran juga berdampak pada kesehatan, 
diantaranya penyakit menular HIV/AIDS yang merupakan risiko umum seks bebas. Pada umumnya seorang pelacur / pekerja seks komersial memiliki wajah cantik dan tubuh yang indah, hal ini dibutuhkan karena merupakan modal dasar untuk terjun dan hidup sebagai pelacur.

Dampak pelacuran akan terus bertambah apabila upaya-upaya pencegahan terhadap perkembangan keberadaan pelacur tidak juga ditangani secara cepat dan efektif oleh pemerintah daerah. Ini semua terkait dengan kebutuhan hidup yang harus dipenuhi, dan jika keadaan sudah buruk, maka seseorang akan melakukan apapun untuk bisa mempertahankan hidupnya tanpa mengenal etika adat istiadat ataupun hukum yang berlaku dimasyarakat.

\section{Permasalahan}

a. Bagaimana efektivitas peraturan daerah Kota Denpasar nomor 2 tahun 2000 dalam memberantas pelacuran di desa sanur kauh, Kota Denpasar?

b. Bagaimanakah kebijakan yang diterapkan dalam hal memberantas pelacuran di desa sanur kauh, Kota Denpasar?

\section{METODE PENELITIAN}

Metode penelitian yang digunakan dalam penelitian ini adalah metode penelitian hukum empiris yang melakukan langkah-langkah penelitian secara terstruktur dan sistematis dengan mengkaji fenomena hukum yang terjadi dalam masyarakat berupa keterikatan antara das sollen dan das sein. Jenis pendekatan yang dilakukan adalah pendekatan fakta hukum dan pendekatan sosiologis dengan melakukan penelitian mengenai efektifitas suatu peraturan di masyarakat. Pengumpulan data dilakukan melalui wawancara dan pengamatan di lapangan serta pengolahan dan analisis data dilakukan secara deskripstif kualitatif.

\section{HASIL DAN PEMBAHASAN}

\section{Efektivitas Peraturan Daerah Nomor 2 Tahun 2000 Dalam Memberantas Pelacuran Di Desa Sanur Kauh, Kota Denpasar}

Hukum pidana positif Indonesia belum mengatur tentang perbuatan pelacuran baik dalam KUHP maupun Undang-Undang diluar KUHP. Pengaturan dalam KUHP tentang delik-delik kesusilaan seperti pada pasal 281 sampai pasal 303, khususnya pasal 296 dan pasal 506 tidak menjerat perbuatan Pelacur maupun pengguna, melainkan hanya menjerat kepada pemilik rumah bordil, mucikari dan makelar atau calo dari perbuatan pelacuran. Sedangkan Undang-Undang di luar KUHP, yakni Undang-undang Nomor 21 Tahun 2007 tentang Pemberantasan Tindak Pidana Perdagangan Orang (yang selanjutnya disingkat UU PTPPO) hanya dapat mempidana seseorang yang mendapatkan keuntungan dari perdagangan orang (mucikari). Undang-Undang Nomor 35 Tahun 2014 tentang Perubahan Atas Undang-Undang Nomor 23 Tahun 2002 tentang Perlindungan Anak hanya mempidana pengguna dari eksploitasi seksual anak.

Pengaturan tentang pelacuran diatur dalam peraturan daerah (yang selanjutnya disebut sebagai Perda) setempat, akan tetapi tidak setiap daerah memiliki peraturan daerah tentang pelacuran. Penegakan hukum terhadap pelacuran melalui peraturan daerah hanya bersifat teritorial karena pengaturannya berada pada peraturan daerah masing-masing sehingga menimbulkan diskriminasi, ketidak adilan dan ketidak pastian hukum karena setiap daerah memiliki budaya hukum yang berbeda-beda baik dalam pengertian pelacuran, pertanggungjawaban pidana pelacuran dan pemidanaan pelaku pelacuran.

Adapun dalam menanggulangi pelacuran, pemerintah daerah menggunakan kebijakan pengaturan yang diwujudkan dalam bentuk lokalisasi atau tempat pelacuran legal. Lokalisasi ini bertujuan untuk mengumpulkan tempat kegiatan pelacuran beserta dampak negatifnya dalam suatu tempat. Dengan adanya kebijakan lokalisasi secara tidak langsung pemerintah melegalkan praktek pelacuran yang bertentangan dengan norma agama, perdagangan orang khususnya wanita dan juga pasal 296 KUHP terkait seseorang yang mengambil keuntungan dari rumah atau kamar yang disewakan dengan tujuan pelacuran. Kebijakan lokalisasi ini sama saja memberikan seseorang kesempatan untuk melakukan perzinahan yang legal menurut hukum, sehingga sudah seharusnya setiap subyek dalam pelacuran yang memiliki keterkaitan dapat mempertanggungjawaban perbuatannya. 
Pemidanaan hanya terhadap mucikari saja tidak mencerminkan rasa keadilan, karena dalam perbuatan pelacuran terdapat subyek-subyek yang berkaitan yakni mucikari, pengguna dan pelacur. Perbuatan pelacuran bagian dari perbuatan zina dikategorikan sebagai (crime without victim) bahwa pelacur dan pengguna termasuk korban tetapi juga sebagai pelaku dalam perbuatannya sehingga hukum Pidana positif Indonesia saat ini masih belum memberikan kepastian hukum yang adil serta pelakuan yang sama dihadapan hukum sebagaimana diamanatkan dalam UUD 1945 Pasal 28D. Langkah pemerintah untuk membebaskan Indonesia pada tahun 2019 dari lokalisasi pelacuran yang saat ini tinggal berjumlah 99 dari 168 lokalisasi yang ada merupakan salah satu bagian dari kebijakan sosial (http://m.tempo.co/read/news/2016/03/04/17350572/menteri-khofifah-2019)

Kegiatan pelacuran di Bali bertentangan dengan norma hukum, norma agama, norma kesopanan, maupun norma kesusilaan. Pemerintah dalam hal ini telah membuat kebijakan hukum pidana dengan mengeluarkan Perda Kota Denpasar No. 2 Tahun 2000 tentang perubahan atas Perda No. 7 Tahun 1993 tentang Pemberantasan Pelacuran di Kota Denpasar. Pelaksanaan penanggulangan terhadap pelacur ini sendiri selaku pihak yang disewa dikenakan sanksi sesuai dengan Perda No. 2 tahun 2000, namun minimnya sanksi yang diberikan tidak membuat efek jera bagi pelaku tindak pidana pelacuran sehingga membuat perbuatan tersebut berulang kembali dan merugikan banyak masyarakat.

Menurut Soerjono Soekanto (2007), salah satu fungsi hukum, baik sebagai kaidah maupun sebagai sikap atau perilaku adalah membimbing perilaku manusia. Masalah pengaruh hukum tidak hanya batas pada timbul ketaatan atau kepatuhan pada hukum, tetepi mencangkup efek total dari hukum terhadap sikap tindakan atau perilaku yang bersifat positif maupun negatif. Efektivitas penegak hukum sangat berkaitan erat dengan efektivitas hukum. Agar hukum itu efektif, maka di perlukan aparat penegak hukum untuk menegakan sanksi tersebut. Suatu sanksi dapat diaktualisasi kepada masyarakat dalam bentuk ketaatan (compliance), dengan kondisi tersebut menunjukan adanya indikator bahwa hukum tersebut adalah efektif,

Menurut Soerjono Soekanto (2007), Faktor-faktor yang mempengaruhi efektivitas hukum antara lain :

\section{a. Faktor Hukum}

Hukum mengandung unsur keadilan, kepastian dan kemanfaatan. Dalam praktek penerapan tidak jarang terjadi pertentangan antara kepastian dan keadilan. Kepastian hokum sifatnya konkret terwujud nyata, sedangkan keadilan bersifat abstrak sehingga ketika seseorang hakim memutuskan suatu perkara secara penerapan perundang-undangan saja ,maka adakalanya nilai keadilan itu tidak tercapai. Maka ketika melihat suatu permasalahan mengenai hokum tidak semata-mata dilihat dari sudut hokum tertulis saja, melainkan juga ikut mempertimbangkan faktor-faktor lain yang berkembang dalam masyarakat. Sementara dari sisi lain, keadilan pun masih menjadi perdebatan disebabkan keadilan mengandung unsur subyektif dari masingmasing orang.

\section{b. Faktor Penegak Hukum}

Penegak hukum berkaitan dengan pihak-pihak yang membentukmaupun menerapkan hukum (law enforcement). Bagian-bagian law enforcement itu adalah aparatur penegak hukum yang mampu memberikan kepastian, keadilan dan kemanfaatanhukum secara proporsional. Aparatur penegak hukum melingkupi pengertian mengenai institusi penegak hukum dan aparat penegak hukum, sedangkan aparat penegak hukum dalam arti sempit dimulai dari kepolisian, kejaksaan, kehakiman, penasehat hukum dan petugas sipir lembaga pemasyarakatan, satiap aparat dan aparatur diberikan wewenang dalam melaksanakan tugas masing-masing yang meliputi kegiatan penerimaan laporan, penyelidikan, penyidikan, penuntutan, pembuktian, penjatuhan vonis, dan pemberian sanksi serta upaya pembinaan kembali terpidana.

Adanya tiga elemen penting yang mempengaruhi mekanisme bekerjanya aparat dan aparatur penegak hukum, antara lain : (a) institusi penegak hukum beserta berbagai perangkat sarana dan prasarana pendukung dan mekanisme kerja kelembagaannya; (b) budaya kerja yang terkait dengan aparat, termasuk mengenai kesejahteraan aparat; dan (c) perangkat peraturan yang mendukung baik kinerja kelembagaannya maupun yang mengatur materi hukum yang dijadikan standar kerja, baik hukum materiinya maupun hukum acaranya. Upaya penegakan hukum secara sistematik haruslah memperhatikan ketiga aspek itu secara simultan, sehingga proses penegakan hukum dan keadilan secara internal dapat diwujudkan secara nyata.

\section{c. Faktor Saranaatau Fasilitas Hukum}

Fasilitas hukum secara sederhana dapat dirumuskan sebagai sarana untuk mencapai tujuan. Ruang lingkupnya terutama adalah sarana fisik yang berfungsi sebagai faktor pendukung. Fasilitas pendukung mencakup tenaga manusia yang berpendidikan dan terampil. Organisasi yang baik, peralatan yang memadai, keuangan yang cukup, dan sebagainya. Selain ketersediaan fasilitas, pemeliharaan pun sangat penting demi 
menjaga keberlangsungan. Sering terjadi bahwa suatu peraturan sudah difungsikan, padahal fasilitasnya belum tersedia lengkap. Kondisi semacam ini hanya akan menyebabkan kontra-produktif yang harus memperlancar proses justru mengakibatkan terjadinya kemacetan.

\section{d. Faktor Masyarakat}

Penegakan hukum bertujuan untuk mencapai kedamaian dalam masyarakat. masyarakat mempunyai pendapat-pendapat tertentu mengenai hukum. Artinya efektivitas hukum juga bergantung pada kemauan dan kesadaran hukum masyarakat. kesadaran yang rendah dari masyarakat akan mempersulit penegakan hukum, adapun langkah yang bisa dilakukan adalah sosialisasi dengan melibatkan lapisan-lapisan sosial, pemegang kekuasaan dan penegak hukum itu sendiri. Perumusan hukum juga harus memperhatikan hubungan antara perubahan-perubahan sosialdengan hukum yang pada akibatnya hukum bisa efektif sebagai sarana pengatur perilaku masyarakat.

\section{e. Faktor Kebudayan}

Faktor kebudayaan yang sebenarnya bersatu padu dengan faktor masyarakat sengaja dibedakan, dikarenakan di dalam pembahasan diketengahkan masalah sistem nilai-nilai yang menjadi inti dari kebudayaan spiritual atau non material. Hal ini dibedakan sebab sebagai suatu sistem (atau sub-sistem dari system kemasyarakatan), maka hukum mencangkup strukur, umpamanya mencangkup tatanan lembagalembaga hukum formal, hukum antara lembaga substansi dan kebudayaan. Struktur mencangkup wadah atau bentuk dari sistem tersebut, lembaga tersebut, hak-hak dan kewajiban-kewajiban dan seterusnya. ( Soerjono Soekanto : $2007: 110$ )

Penanggulangan pelacuran di Bali khususnya di Desa Sanur Kauh, Kota Denpasar merupakan masalah yang kompleks dan rumit. Di katakan kompleks, karena masalah pelacuran menyangkut kehidupan manusia yang disebabkan oleh berbagai aspek seperti sosial, budaya, ekonomi, ketertiban dan keamanan lingkungan. Penanggulangan pelacuran dikatakan rumit, karena menyangkut sikap mental sehingga penanggulangannya harus secara professional dengan rencana yang matang serta pelaksanaan kegiatan yang terarah, terpadu dan berkesinambungan. Melalui data yang penulis peroleh dari lokasi penelitian, data jumlah pelacur di Desa Sanur kauh pada tahun 2014, terdapat 188 pelacur dari 24 tempat pelacuran serta terdapat 3 tempat hiburan atau cafe, di tahun 2015 hingga saat ini (2019) Desa Sanur kauh sudah tidak melakukan pendataan jumlah pelacur, sehingga pendataan dikhususkan hanya untuk warga pendatang. Sehingga, agak sulit mendeteksi keberadaan dari para pelacur yang berbaur dengan masyarakat, hal inilah yang harus mulai dilakukan kembali sehingga mempermudah mendeteksi dan mencegah meluasnya penyakit masyarakat di lingkungan Desa Sanur.

\section{Kebijakan Yang Diterapkan Dalam Hal Memberantas Pelacuran Di Desa Sanur Kauh, Kota Denpasar}

Budaya hukum (legal culture), merupakan penekanan dari sisi budaya secara umum, kebiasaankebiasaan, opini-opini, cara bertindak dan berpikir, yang mengarahkan kekuatan social dalam masyarakat. Menurut Lawrence M. Friedman dalam Otje Salman dan Anton F. Susanto (2004):153 bahwa : "Setiap sistem hukum selalu mengandung tiga komponen, yaitu komponen Struktur Hukum (legal structure), Substansi Hukum (Legal Substance) dan Budaya Hukum (Legal Culture). Sistem hukum dalam kenyataan sulit untuk dilaksanakan dalam berbagai organisasi yang akan mempengaruhi struktur, substansi dan budaya." (Ontje Salman dan Anton F Susanto : 2004 :153)

Komponen- Komponen dalam Sistem Hukum sangat mempengaruhi pelaksanaan suatu sistem hukum di masyarakat, efektif tidaknya suatu aturan hukum bukan merupakan tugas Pemerintah saja dalam upaya penegakan hukumnya, namun segala komponen berperan serta dalam upaya mewujudkan terlaksananya suatu sistem hukum. Dalam hal pemberantasan pelacuran di Desa Sanur, peran desa baik desa adat maupun desa dinas merupakan bagian yang tidak terlepas termasuk masyarakat yang seharusnya berperan aktif untuk mencegah maupun menanggulangi dampak yang timbul dari perkembangan pariwisata yang sangat pesat termasuk dampak penyakit masyarakat berupa pelacuran atau prostitusi.

Dalam hal ini langkah-langkah yang dilakukan dalam penanggulangan pelacuran dari Desa Sanur Kauh dengan menggunakan langkah persuasif, langkah persuasif yaitu Pengendalian sosial yang dilakukan tanpa kekerasan misalnya melalui cara mengajak, menasihati atau membimbing anggota masyarakat agar bertindak 
sesuai dengan nilai dan norma masyarakat. Desa adat berpartisipasi aktif dalam upaya pemberantasan kegiatan pelacuran, untuk itu hal-hal yang dilakukan sebagai berikut :

a. Melakukan pendataan administrasi penduduk khususnya penduduk pendatang.

b. Mulai melakukan pendataan kembali terhadap pelaku pelacuran sehingga mempermudah untuk mendeteksi dan pengawasan serta secara perlahahan melakukan pemberantasan

c. Masyarakat harus bersama-sama dengan pihak desa melakukan pemberantasan dan penanggulangan pelaksanaan pelacuran dengan selalu proaktif dalam mendeteksi keberadaan-keberadaan tempat-tempat yang dicurigai memiliki bisnis prostitusi

d. Bekerjasama dengan Karang Taruna, Yowana Kerthi Bhuana dan Lembaga Pemberdayaan Masyarakat (LPM) melakukan sosialisasi tentang penyakit HIV/Aids secara rutin.

e. Melakukan sidak identitas diri ( e-ktp ).

f. Bekerjasama dengan Dinas Kesehatan melakukan pemeriksaan kesehatan terhadap para pelacur, untuk mengantisipasi adanya penularan penyakit HIV/Aids.

\section{SIMPULAN DAN SARAN}

\section{Simpulan}

1. Pelaksanaan Peraturan Daerah Kota Denpasar Nomor 2 Tahun 2000 tentang pemberantasan pelacuran belum efektif, hal ini dikarenakan masih adanya praktik pelacuran di Desa Sanur Kauh dan pemberian sanksi-sanksi dalam praktik pelacuran tidak menimbulkan efek jera terhadap pelacur, pengguna jasa, maupun penyedia tempat, selain itu praktik pelacuran ini merupakan salah satu fenomena yang sulit diselesaikan oleh pihak Desa Adat Sanur Kauh karena ketika dilakukan pemberantasan terhadap praktik pelacuran tersebut terjadi benturan dengan pihak masyarakat karena dianggap menunjang perekonomian mereka.

2. Desa Adat Sanur Kauh tidak memiliki kebijakan hukum khusus terkait dengan permasalahan pelacuran, seperti peraturan desa ataupun awig-awig, tetapi dari pihak Desa Sanur Kauh tetap melakukan pengawasan dan juga pembinaan terhadap tempat-tempat pelacuran di wilayah Desa Sanur Kauh.

\section{Saran}

1. Kepada Pemerintah Desa melakukan tindakan persuasif, melakukan pendekatan terhadap tokoh-tokoh masyarakat di Desa Sanur Kauh, agar mereka membantu pemerintah desa untuk melakukan sosialisasi mengenai dampak negatif dari praktik pelacuran. Kemudian kepada Pemerintah Kota dan Pemerintah Desa bersinergi untuk melakukan pemberantasan terhadap praktik pelacuran, dengan itu pemerintah desa tidak bekerja sendiri dalam menangani permasalahan pelacuran di Desa Sanur Kauh tersebut.

2. Untuk masyarakat harus memahami atau mengetahui dampak buruk dari paradigma pelacuran di Desa Sanur Kauh tersebut, selain memberikan dampak negatif dari kesehatan juga berdampak pada pencitraan atau nama baik desa tersebut.

\section{DAFTAR PUSTAKA}

Ahmad Wardi Muslich, 2005. Hukum Pidana Islam. Sinar Grafika, Jakarta.

Ahmadi Abu, 1982. Psikologi Sosial. PT. Bina Ilmu, Surabaya.

HortonPaul Bdan Chester L. Hunt, 1993, Sosiologi, Jilid 1 Edisi Keenam, (Alih Bahasa: Aminuddin Ram, Tita Sobari), Penerbit Erlangga, Jakarta.

Kartono Kartini, 2005. Patologi Sosial, Jilid I. PT Raja Grafindo Persada, Jakarta.

Soerjono Soekanto, 2007. Pokok-Pokok Sosiologi Hukum. PT. Raja Grafindo Persada, Jakarta.

Lawrence M. Friedman, 1975. The Legal System; A Social Scince Prespective, Russel Sage Foundation, New York

Otje Salman dan Anton F. Susanto. 2004 Teori Hukum : Mengingat, Mengumpulkan dan Membuka Kembali., PT. Refika Aditama, Bandung 


\section{Jurnal}

Yulianto Bambang Setyadi, 2007. Pariwisata dan Perubahan Nilai-nilai Sosial Budaya Berdasarkan Lingkungan Tradisi Pada Masyarakat Bali ( Tourism and The Changes Of Social-Cultural Values Based On The Traditional Environment In Bali), Vol 8, No 2, Jurnal Penelitian Humaniora

Agustinus Ola Boli “ Implementasi Peraturan Daerah Nomor 18 Tahun 2002 tentang Penertiban dan Penanggulangan Pekerja Seks Komersial Di Kota Samarinda “E-Journal Pemerintahan Volume 2, $2014: 1817-1828$

Anak Agung Gede Triyatna, I Gusti Ngurah Parwata, “ Kriminalisasi Terhadap Perbuatan Pekerja Seks Komersial Dalam Pembaharuan Hukum Pidana" Jurnal Kertha Wicara, Volume 8 Nomor 4 Tahun 2019

\section{Peraturan Perundang-Undangan :}

Undang-Undang Dasar Negara Kesatuan Republik Indonesia Tahun 1945

Kitab Undang-undang Hukum Pidana

Peraturan Daerah Nomor 2 tahun 2000 Tentang Pemberantasan Pelacuran 